\title{
Veracities of teaching listening in Nepal
}

\author{
Nanibabu Ghimire \\ Tribhuvan University, Nepal
}

\begin{abstract}
This study explores realities, problems and their solutions of teaching listening in English in secondary level education in Nepal. As it is a narrative inquiry, I chose three English teachers and six students from three different secondary level community schools of Kamalamai Municipality of Sindhuli district, Nepal as the participants of the study using purposive sampling procedure. The findings demonstrated that the listening skill is the neglected skill in our school education. The teachers do not pay much more attention to teach this skill in our community school by thinking teaching listening is not important for examination purpose. There is scarcity of audio-visual devices, the classroom is not techno-friendly, teachers are not dedicated and trained, monitoring strategies of concerned authority is not effective for teaching listening. Recommended solutions include - the students should be proactive and the school administration has to be responsible for making availability of listening equipment and materials. Similarly, the teachers should use various interactive and cooperative activities such as role-play, pair work, group work and communication games using authentic materials such as English films, favourite songs, funny short stories, some exciting programmes on radio, TV or the internet for the effectual teaching of listening.
\end{abstract}

Key words: ELT, Teaching listening, Reality, Problem, Community School, Nepal

\section{Introduction}

Listening is one of the most fundamental and inseparable skills of teaching and learning of English. It is a primary language skill for foreign language learners to acquire. Similarly, listening refers to the ability that enables the learners to identify and understand the natural or recorded speech of someone. Speech involves pronunciation of consonant and vowel sounds, stress, rhythm and intonation. So, listening is directly related to these aspects of speech. Khaniya (2005, p.124) said;

Listening is a complex process. In listening, the listener receives the incoming data, an acoustic signal and interprets it on the basis of a wide variety of linguistic and nonlinguistic knowledge. The linguistic knowledge includes knowledge of 
phonology, lexis, syntax, semantics, discourse structure, pragmatics ad sociolinguistics. The non-linguistic knowledge includes knowledge of the topic, the context and general knowledge about the world and how they work.

Chastain (1971) defined listening as the ability to understand native speech at normal speed. Morley (1972) said that listening involves auditory discrimination, aural grammar, selecting necessary information, remembering it, and connecting it to the process between sound and form of meaning. Likewise, Richards et al. (1999, p.16) delineated listening as "the process of understanding speech in a second or foreign language". Similarly, in Underwood's (1989, p.1) words, "Listening is the activity of paying attention to and trying to get meaning from something we hear." Anyway, we receive messages or information through listening. It is taken to mean trying to understand the oral message people are conveying.

As English is an international language, it is learned for some specific purposes, mostly to communicate with the foreigners. Usually, English is taught as a foreign language in Nepal, but it is very rarely used as a language of communication. All four language skills are equally significant in language teaching. In past, reading and writing were duly emphasized but, now most of the linguists are convinced that listening and speaking are the primary skills of language learning. Nowadays much attention is paid towards the listening and speaking because the learners cannot learn language if they have not lots of the practice in listening and speaking. Regarding this, all language skills have been given due importance in our school education since the introduction of National Education System Plan,1971. The objective of the listening skill in Secondary Education Curriculum (1973) was, "to enable the students to understand simple conversation and normal speech deliver towards him."

Listening is a basic skill to be developed for language learners. The learners cannot learn languages without proper development of listening. Morris and Leavey (2006) mentioned that language learning depends greatly on listening due to the fact that it is the skill that provides the primary impulse that initiates first, second and foreign language learning. If we go through the curriculum, textbook, and other materials of English of secondary level in Nepal, we find that high emphasis is placed on listening skills. It is claimed that the students have not developed their capacity in proper manner in this skill. My own experiences confirm that the students of the community schools of Nepal do not understand English language. They cannot speak English without any kind of hesitation. They do not understand and comprehend when they listen to cassette or other materials. In this consideration, Walker (2014, p. $170)$ asserted listening skill as:

With listening skills usually requiring a considerably long period of time to acquire, normally involving the student experiencing a variety of emotions ranging from depression and frustration through to exhilaration and pride, teaching 
listening skills is one of the most difficult tasks that a teacher faces.

There is a provision of various activities of teaching listening in the textbook of secondary level, but the students have not practiced them a lot because teachers neglect to teach listening in the classroom. However, Buck (2001, p.31) pointed out that listening is an active process of constructing meaning by utilizing knowledge to the incoming sound in which both linguistic and nonlinguistic knowledge are involved. I regarded this as a problem in ELT in our school education system and I am keenly interested to explore this issue.

\section{Purpose and research question of the study}

The main purpose of the study was to explore the current practices and problems of teaching listening in English in secondary level education in Nepal. The study was guided by the following research questions:

- What practices do the teachers accomplish in teaching listening skill in English at secondary level (Grade 9 and 10)?

- What problems do the teachers come across regarding the practices of teaching listening skill in English at secondary level (Grade 9 and 10)?

- What suggestions do teachers provide to mitigate challenges in teaching listening skill at this level?

\section{Review of literature}

Listening is a fundamental language skill to acquire before other skills. It is an active process of perceiving and constructing a message from a stream of sounds. Listening plays a significant role in daily communication and educational process. Mendelsohn (1994) claimed, "out of the total time spent on communicating, listening takes up 4050\%; speaking, 25-30\%; reading, $11-16 \%$; and writing, about 9\%". Nunan (1998) opined that listening involves an active process of deciphering and constructing meaning from both verbal and nonverbal messages. Harmer (1998, p. 25) mentioned;

listening activities are different from other classroom exercises in a number of ways; firstly, tapes go at the same speed for everybody unlike language study or speaking practice or over reading where individual student can read it to some extent at their own pace. In listening the tape continues even if some individual lost.

Osada (2004) explains that listening is in fact vital for the language learning but at the same time a complex process. Due to the amount of effort to acquire to the learners to listen, which must comprehend what it been said, retain the information in memory, integrated with what is being said and continually adjust its understanding of what its heard in the light of prior knowledge and incoming information. Richards (2008) revealed that the teaching of listening has attracted a greater level of interest in recent years than it did in the past. Now, university entrance exams, exit exams, 
and other examinations often include a listening component, acknowledging that listening skills are a core component of second-language proficiency, and reflecting the assumption that if listening is not tested, teachers will not teach it.

In a research entitled 'Adopting Computer Assisted Language Learning to Promote Listening Skills for EFL Learners in Vietnamese Universities' Phuong (n.d.) stated, "the use of recent digital technologies to enhance the teaching and learning of listening skill is still limited". Timalsina (2000) found that the live voice of the teacher was much more effective than the recorded materials. In the same way, in a research 'Listening Proficiency of Grade Ten Students of Gorkha District' Aryal (2001) discovered that students' proficiency was better in the seen text in comparison to the unseen one. Likewise, Rana (2002) held a research entitled 'Listening Ability of the Nepalese Learners of English' and located that listening abilities of the Nepalese learners of English are determine to be $85.95 \%$. The listening abilities of engineering students are the highest, i.e. $87.02 \%$. Talking about the problems of teaching listening in school education Underwood (1989) described thatthe learners have no control over the speed at which speakers speak and they are not being able to get things repeated, they have limited vocabulary and become failure to recognize the "signals". There are problems of interpretation, concentration, and establishment of learning habits.

Bloomfield, Wayland, Rhoades, Blodgett, Linck, and Ross, S. (2010, p. 6) emphasised as "if a listener is anxious or in some other way distracted and unable to pay attention, it will be more difficult to accurately determine what was said". Graham (2006) suggested that there are some other factors that increase learners' listening comprehension problems such as restricted vocabulary, poor grammar, and misinterpretations about listening tasks. Regarding the ways of solution to improve listening skill in students Kurita (2012, p. 41) concluded as "The final goal of developing listening might be to enable learners to become autonomous learners. Appropriate instruction for listening comprehension can reduce listening anxiety and provide a good foundation for becoming autonomous learners who can utilize the listening process for acquisition". Goh (2000) believed that it is very important to teach listening strategies to students and before doing this, teachers should increase learners' knowledge of vocabulary, grammar, and phonology. I have selected this area to explore the problems and current practice in teaching listening in our school education.

\section{Methodology}

I followed the qualitative approach and interpretative paradigm in this study. The interpretive paradigm is concerned with understanding the world as it is from subjective experiences of individuals believing on multiple realities. Creswell (2003, p.18) stated "a qualitative approach is one in which the inquirer often makes knowledge claims based primarily on constructivist perceptive or advocacy/participatory perspectives or both". Regarding method, I chose narrative inquiry as the research design. Polkinghorne (1995, p. 
5) describesnarrative inquiry as "a discourse form in which events and happenings are configured into a temporal unity by means of a plot". Narrative inquiry follows a recursive, reflexive process of moving from field (with starting points in telling or living of stories) to field texts (data) to interim and final research texts. Narrative inquiry tries to express person's experience through narration. Baden and Major, (2010, p. 73) affirmed, "narrative inquiry is the telling (or retelling) of a story or set of events in a specific time sequence and is a human meaning making tool, the process by which individuals explore and later explain their experiences". I tried to see participant's interpretation of their experience and their reconstruction and reconfiguration of challenges with a view to preventing them.

I chose three English teachers from three different secondary level community schools and six students for focus group discussions from the sameof Kamalamai Municipality of Sindhuli district, Nepal as the participants of the study using nonrandom purposive sampling procedure. I used interview guidelines to collect data. Cohen, Manion and Morrison (2011) stated, "Interview is the process of interchanging view with one another. It is a flexible tool for data collection, enabling multi-sensory channel to be used; verbal, non-verbal, spoken and heard". The collected raw data was transcribed, the different opinions of the participants was organized in three global themes by making codes and they were analysed and interpreted with the help of related literature and participants' claims.

\section{Results and discussion}

This section discusses the results of the study in terms of reality, problems and ways of solution of teaching listening. I have provided bogus names for each participants as Teacher ' $A$ ', ' $B$ ' and ' $C$ '.

\section{Reality of teaching listening}

There is a provision of listening exercises in the textbook of class 9 and 10 in Nepal. The listening cassette is also available in the market. The teachers are also trained to teach listening. People make comment that the teachers do not teach listening in the class. I tried to come across the experiences and understanding of the participants on the realities of teaching listening in secondary level community school of Nepal. In this regard, Teacher A said, "Neither teachers nor students pay attention to listening skill. My students listen to authentic cassette only in their final examination. I collect the transcription of listening text and I read loudly, they do the activities by following me".

The accounts made by Teacher A shows that both teachers and students have neglected the listening skill. This is in line with Osada (2004, p.57) who contend listening as a "somewhat neglected and poorly taught aspect of English". The students do not have opportunity to listen authentic cassette in the classroom. The teachers do not have access to the cassette and they taught listening by reading transcription of listening text. However, the remarks made by Teacher $B$ is different from Teacher A. Teacher B expresses, "my students listen to cassette in the classroom and involve in the 
listening activities following prelistening, while listening and post listening stages. Their listening comprehension is poor because they cannot answer simple question as well.

The report illustrates that Teacher $\mathrm{B}$ teaches listening by playing cassette in the classroom. He follows the stages of teaching listening but his students are poor in listening regarding listening comprehension. For this, Bekleyen (2007, p.104) suggests that the materials used in a language class should be chosen carefully. In addition to audio cassettes or CD's, visual materials should also be included in the lessons so that students can make use of visual cues and can understand listening easily. The classroom organisation should also facilitate interaction of which listening is an integral part. For example, Hwaider (2017, 142) mentioned as, "classroom organization should encourage interaction, allowing pairing and grouping of students" for effective teaching in developing listening skill of the students.

Likewise, Teacher C said, "the listening skill is not prioritized in community school. I have not got any kinds of training and materials for teaching listening. The student neither studies nor practices listening in school ". This excerpt exposed that the condition of teaching listening in community school is very pitiable. The students do not haveopportunities to learn this skill using listening devices as well as materials with trained teachers. Because of this, students regard listening skill is the most difficult language skill in ELT. Pointing out the reason for this, Vandergrift (2007) stated that one of the reasons might be that learners are not taught how to learn listening effectively. Instead of negligence in teaching listening Morley (1991, p.82) conveyed as "we can expect to listen twice as much as we speak, four times more than we read, and five times more than we write" to improve listening. Realizing the same fact in a focus group discussion the students expressed their idea as "We do not listen to the cassette of listening text. We are told that the listening exercises are not important for the examination. We only listen to the cassette in SLC/SEE examination".

The thoughts expressed by the teachers and students indicate that there is not apposite environment to teach listening in community school. The attitudes of teachers towards listening skill is negative. They do not like to teach and practice listening in the classroom. But listening skill is the most important skill to develop students' English language. Because of this negligence of the listening skill, our students are weak in English language. Suggesting a solution for this, Gilakjani and Sabouri (2016, p. 1675) indicated that learners should be provided with appropriate materials and activities in which they can learn how to understand the English language. Teachers should give learners the opportunity to listen to native speakers' speech, and choose listening texts that are recorded by non-native speakers so that they can develop their listening skills.

\section{Problems in teaching listening}

The government has set a system of taking the listening and speaking test in 
SLC/SEE examination. However, teachers have many problems in teaching this skill. One of the participants of this research Teacher A said, "Our classroom is not appropriate for teaching listening because it is disturbed by other noise while playing cassette. There is not a separate language lab in my school". It is evident that the physical infrastructure of our school is not suitable for teaching listening. There is no provision of technofriendly classroom and language lab in our community school. Bingol,Celi, Yildizand Mart (2014, p.4) opined as:

Inconvenience of classrooms affects students listening comprehension. In the large classrooms students who are sitting on the back rows may not hear the recording as students sit in front. Students who prefer to stay next to the windows also affected by the noise that come from outside... still there are some classrooms do not have computer, smart board, multimedia systems and so on.

Reiterating the problems in teaching listening in community school of Nepal, Teacher B explained "the major problem of teaching listening is the lack of modern listening devices and equipment. I use my personal mobile phone as a device for teaching listening. Cultural diversity of the students is another problem".

The main problems of teaching listening in Nepalese community school are the lack of a provision for listening devices and equipment. The teachers have been using their personal mobile phones for teaching listening. I think the sounds of mobile is not loud enough in large classrooms. Hwaider (2017, 142) discussed that listening is considered as a visual as well as an auditory act, as people communicate much through body language. These visual supports can improve listening comprehension. Therefore, unavailability of these visuals or inability to use them effectively in classroom leads to difficulties in listening comprehension. In the same way, the mixed ability and the multilingual students are a challenge to teach listening in ELT classroom because it is difficult to deal with individual students with specific challenges. As Bingol, Celi, Yildizand Mart (2014, p.3) asserted, being unfamiliar with cultural knowledge of language plays a great role in understanding the context. For instance if the listening part is about Easter Day and it is not a common practice locally, it is extremely difficult for students to understand it. The text need to be selected as the nature of our own society. Anderson and Lynch (1988) also averred that lack of sociocultural, factual, and contextual knowledge of the target language could present an obstacle to comprehension because language is used to express its culture. The view of Teacher $\mathrm{C}$ on the problems of teaching listening is, "teachers are not dedicated to teach listening. There is no monitoring from any government agencies to check if the teacher is teaching listening or not". Therefore, it can be said that the teacher do not feel responsible for managing listening equipment as well as handling the class properly at the time of teaching listening. Tersta and Novianti (2017, p. 33) claimed:

Students may face the difficulties of the listening and the teacher need to emphasize the listening in the learning process. Furthermore, the problem also arises when the listening 
comprehension does not get attention from the teacher. Some of the teacher and the institution tend to neglect listening comprehension and pay more attention to structure, writing, reading and vocabulary. As a result, the students tackle many problems on their listening comprehension.

The students express the view that they got limited opportunity to listen to audio text but they felt difficult to understand it.The needed more practice. For this Goh (1999) suggests that the most common problems faced by students in listening in the order of frequency are quickly forgetting what is heard, not recognising the words they know, understanding the message but not the intended message, neglecting next part while thinking about meaning, being unable to form a mental representation from words heard.

\section{Solving problems of teaching listening}

The respondents suggested different strategies to solve the problems of teaching listening. In this concern, Teacher A remarked:

We must have professional honesty and dedication. We should try to develop the listening comprehension of the students by using effective teaching activities oflistening and the students should also be proactive to listen and comprehend native speakers'voice.

The teacher himself is saying that they need to be dutiful and dedicated to teach listening to the students. If the teachers are honest, they can collect audio cassettes. Likewise, the students themselves should be active as well as creative to learn listening skill effectively. Similarly, it was suggested that students needed to be more willing to listen actively to what the speaker says and they should have much more exposure to variety of listening for meaningful learning.

Teacher B agreed and added, "the classrooms need to be technology friendly and teachers have to be trained and familiar with modern information technology". The school management and teachers themselves need to be sensitive to make techno-friendly physical infrastructure. As Tersta and Novianti (2017, p.35) maintained, it would be better for the school or the teacher to provide some machines so the students can hear in appropriate situation, or invited the students in the language center so they can practice listening more. Similarly, Teacher C uttered, "the concerned authority need to monitor the listening activities at school and they must try to make SLC/SEE examination of listening and speaking effective to improve the listening comprehension in students".

TheNepalese education system is examoriented, therefore, the authority of Nepal need to take initiation for effective examination of listening and speaking from Grade 6 through which there can be change in teaching. In this regard a students said, "the teacher should be active as well as laborious to teach listening and we also need to be curious in developing our listening skill. There should be an effective management of the listening equipment in the school". 
The observations of the students divulged that the teachers could at least provide the students with suitable listening materials, background and linguistic knowledge, enabling them to develop skills, pleasant classroom conditions, and useful exercises to help them discover effective listening strategies.As Y1lmaz and Yavuz (2015)recommends, learners should be well equipped with authentic language opportunities to develop strategies such as taking notes, making practice, or having methods for feeling themselves relaxed during listening.

\section{Conclusion}

Listening is one of the most fundamental and inseparable skills of learning English. Listening comprehension is an important part of language learning because the key to learn a language is to receive language input. The teachers have neglected the listening skill in the community school of Nepal. The students are not provided with enough opportunities to listen to authentic cassettes in the classroom, therefore, they are poor in listening comprehension. The condition of teaching listening in community school is very pitiable in the sense that the students do not have a chance to learn this skill with trained teachers. The students regard listening skill as the most difficult language skill. The teachers think that listening is not necessary to teach to the students and they skip the lessons of listening. Because of this negligence of teaching listening skill, our students are weak in English in our school.
There are many problems in teaching listening in the community schools of Nepal. The physical infrastructure of our school is not suitable for teaching listening. There is no provision of technofriendly classrooms, language lab and audio-visual devices in our community school. The noise that comes from nearby class disturbs the teachers and students to listen the cassette clearly The teachers have been using their personal mobile phone for teaching listening; the sounds of mobile is not enough in large classrooms. The students feel difficultyin understanding when they listen to the cassette.There is a lack of monitoring from the concerned agency.

Based on the discussion above, the following recommendations are made by the teachers as well as by the students. The teachers need to be dutiful and dedicated to teaching listening to the students to overcome the problems listening. The teachers can collect audio cassette themselves even if school administration does not provide them. Likewise, the students should themselves be active as well as creative to learn listening skill effectively. The physical setting is an external factor which influences the students on listening tp the tape recorder in the class. The school management needs to be sensitive to make techno-friendly physical infrastructure for teaching listening. The authority of Nepal needs to take initiation for effective examination of listening and speaking. The teacher can at least provide the students with suitable listening materials, background and linguistic knowledge, enabling skills, pleasant classroom conditions, and useful 
exercises to help them discover effective listening strategies.

\section{Implication for teachers}

As Rost (1994) mentioned, listening is necessary since it provides input for the learner; teachers need to make students aware about the significance of the listening skills and stimulate them towards this skill. Students should identify that the listening skill is one of the four fundamental language skills that helps them communicate efficiently and learn other skills better. The teachers have to spend time to collect listening devices, equipment and materials to make them available to the students to teach listening effectively. It is necessary that teachers are acquainted with students' learning preferences, language competence and need to adapt the tasks so that they are appropriate with their students' interests and abilities. Moreover, teachers should use various interactive and cooperative activities such as role-play, pair work, group work and communication games in order to draw the attention of students in excited discussion.

Furthermore, teachers ought to utilise an assortment of teaching learning materials with full of attraction to appeal to students towards the lesson in teaching listening. Visual aids and drawing pictures should be prepared to stimulate students' imagination. The teachers should also use other authentic materials such as English films, favorite songs, funny short stories, interesting news and conversations, some exciting programmes on radio, TV or the internet in order to reduce students' boredom and indifference during listening periods. By doing this, students not only are motivated to learn but also approach the real world listening to develop their listening skills.

\section{References}

Anderson, A. \& T. Lynch. (1988). Listening. London: Oxford University Press.

Aryal, K. M. (2001). Listening proficiency of grade ten students. An Unpublished M. Ed. Thesis.Kathmandu; T.U.

Baden, M. S. \& Major, C. H. (2010). New approaches to qualitative research. London: Routledge.

Bekleyen, N. (2007). An investigation of English teacher candidates' problems related to listening skill. Elektronik Sosyal Bilimler Dergisi, 6 (21), 91-105. Retrieved from: https:// dergipark.org.tr/download/articlefile/ 69971

Bingol, M. A.,Celik, B., ,Yildiz, N. \& Mart, C. T. (2014). Listening comprehension difficulties encountered by students in second language learning class. Journal of Educational and Instructional Studies in the World, 4 (4), 1-6. Retrieved from:http:// www.wjeis.org/FileUpload / ds217232/File/01b.bingol.pdf

Bloomfield, A., Wayland, S. C., Rhoades, E., Blodgett, A., Linck, J., \& Ross, S. (2010). What makes listening difficult? Factors affecting second language listening comprehension. Retrieved from: https:// pdfs.semanticscholar.org/b1de/ 1 ba 87 c 29 d 6 a 6 efaeed 65347 da 9 4eb5a7e0d1.pdf 
Bowen, G. A. (2009). Document analysis as a qualitative research method. Qualitative Research Journal, 9(2), 2740. doi:10.3316/QRJ0902027

Buck, G. (2001), Assessing Listening, Cambridge: Cambridge University Press.

Chastain, K. (1971). The Development of Modern Language Skills: Theory to Practice. Philadelphia: Center for Curriculum Development.

C.D.C.(2030).Secondary education curriculum.SanothimiBhaktapur: Janak Education Materials Center.

Cohen, L.,Manion, L. \& Morrison, K. (2011). Research methods in education (7th ed.). London: Rutledge Flamer, Taylor \& Francis Group.

Co. T.V. (2009). Improving weak student's listening skills.Honai: 5th National VTTN ELT Conference.

Creswell, L. W. (2003). Research design: Qualitative, quantitative and mixed methods approaches. Sage Publication.

Dunkel, P. (1991). Listening in the native and second/foreign language: Toward an integration of research and practice. TESOL Quarterly, 25, 431457.

Gardner, R. and W. Lambert (1972), Attitudes and Motivation in SecondLanguage Learning, Rowley, Ma: Newbury House.

Gilakjani, A. P. \&Sabouri, N. B. (2016). The significance of listening comprehension in English Language teaching. Theory and Practice in Language Studies, 6 (8), 1670-1677. DOI: http://dx.doi.org/10.17507/ tpls.0608.22

Graham, S. (2006). Listening Comprehension: The Learners' Perspective. System, 34, 165182.http://dx.doi.org/10.1016/ j.system.2005.11.001

Goh, C. (2000). A cognitive perspective on language learners' listening comprehension problems. System, 28(1), 55-75. Retrieved from:http:// hdl.handle.net/10497/18662

Hamouda, A. (2013). An Investigation of Listening Comprehension Problems Encountered by Saudi Students in the EL Listening Classroom. International Journalof Academic Research inProgressive Education and Development, 2(2), 113-15. Retrieved from: http:/ / hrmars.com/admin/ pics/1882.pdf

Harmer, J. (1998). The practice of English language teaching. London: Longman.

Hennings, D. G. (1992). Beyond the read aloud: Learning to read through listening to and reflecting on literature. Bloomington, IN: Phi Delta.

Hwaider, S. M. (2017). Problems of Teaching the Listening Skill to Yemeni EFL Learners. International Journal of Scientific and Research Publications, 7( 6), 140-148. Retrieved from: http:// www.ijsrp.org/research-paper-0617/ ijsrp-p6619.pdf

Khaniya, T. R. (2005). Examination for enhanced learning. Lalitpur: Millennium Publication.

Kurita, T. (2012). Issues in second language listening comprehension and the 
pedagogical implications. Accents Asia, 5(1), 30-44. Retrieved from: http: / / citeseerx.ist.psu.edu / viewdocdownload?doi=10.1.1.473.3299 $\& r e p=$ rep $1 \&$ type $=p d f$

Mendelsohn, D. J. (1994). Learning to listen: A strategy-based approach for the second language learner. San Diego: Dominie Press.

Morley, J. (1991), “Listening Comprehension in Second or Foreign Language Instruction", in M. CelceMurcial (Ed.), Teaching English as a Second or Foreign Language (2nd .ed.), pp. 81-106, New York: Newbury House.

Morley, J. (2001). Aural Comprehension Instruction: Principles and Practices. In M. Celce-Murcia (Ed.), Teaching English as a Second or Foreign Language (69-85) Boston: Heinle and Heinle.

Morris, T., \& Leavey, G. (2006). Promoting phonological awareness in nurseryaged children through a Sure Start Early Listening programme. International Journal of Early Years Education, 14(2), 155-168.

Nunan, D. (1998). Approaches to Teaching Listening in the Language Classroom. Paper presented at the Korea TESOL Conference, Seoul.

Osada, N. (2004). Listening comprehension research: A brief review of the past thirty years. Dialogue, 3(1), 53-66. Retrieved from http:// www.talkwaseda.net/dialogue/ no03_2004/2004dialogue03_k4.pdf

Phuong, L. T. (.....). Adopting CALL to promote listening skills for EFL learners in Vietnamese universities. PIEXEL:
International Conference "ICT for Language Learning" 4th Edition.

Polkinghorne, D. E. (1995) Narrative configuration in qualitative analysis, in: J. A. Hatch \& R. Wisniewski (Eds) Life History and Narrative. London: Falmer Press.

Richards, J. C.(2008). Teaching listening and speaking from theory to practice. Cambridge: CUP

Richards, J. et al. (1999). Longman dictionary of language and applied linguistics.Essex:Longman.

Rost, M. (1994). Introducing listening. London: Penguin Group.

Santos, R. S. (2018).Improving Young Learners' Listening Skills Through Storytelling. Retrieved from:https:// run.unl.pt/bitstream/10362/47622/ 1/Final \% 20report $\% 20 \% 20$ Rubina $\% 2$ 0Santos\%20May \% 202018\%20Vers\% C3\%A3o\%20 melhorada.pdf

Tersta, F. W., \&Novianti A. (2017). Listening to students' voices: Students' Problems in listening comprehension. Advances in Social Science, Education and Humanities Research (ASSEHR), 82, 33-36. Retrieved from: http:// creativecommons.org/licenses/bync/4.0/

Timalsina, T. R.(2000). Effectiveness of recorded materials over conventional techniques. An Unpublished M. Ed. Thesis. Kathmandu: T.U.

Underwood, M.(1989). Teaching listening. London: Longman. 
Vandergrift, L. (2007). Recent developments in second and foreign language listening comprehension research. Language Teaching, 40, 191210. doi: 10.1017/S0261444807004338

Walker, N. (2014). Listening: the most difficult skill to teach. Encounter, 23, 167-175. Retrieved from: https:// core.ac.uk / download / pdf / 58911108.pdf

Walker, N. Listening: the most difficult skill to teach.Encuentro23, 2014, ISSN 19890796, pp. 167-175

Yadav, Y.P. (2004).Linguistics A basic course. Kathmandu: New Hira Books Enterprises.

Yagang, F. (1993). Listening: Problems and solutions. Retrieved on Jane 30, 2019 fromhttp:/ / www.valrc.org/courses/ ESOL \% 20basics / ESOL \% 20Basics / Lesson \% 205/Listening.pdf

Y1lmaz, H., \&Yavuz, F. (2015). The problems young learners encounter during listening skills. Procedia-Social and Behavioral Sciences, 197, 20462050.

\section{Appendix I}

\section{Interview guideline}

1. What are the ground realities of teaching listening in secondary level (Grade 9\&10) of the community school?

2. What devices or equipments are used in teaching listening?

3. How do these devices use during teaching listening?
4. What activities do you apply while teaching listening?

5. How do you describe the problem of teaching listening in secondary school?

6. What support do you achieve from school administration in teaching listening?

7. Is there any monitoring system for teaching and evaluation of listening?

8. How do you suggest solving the problems of teaching listening?

9. How do students assist you to support in teaching listening?

10. Who can help you to address the problems of teaching listening?

\section{Contributor: Nanibabu}

Ghimire is a lecturer at Siddha Jyoti Education Campus Sindhuli, Nepal. He has completed Master's Degree in English Education and English in Arts from Tribhuvan University. He is currently a Ph. D. scholar in English Education at Tribhuvan University. He is interested in teacher professional development, multilingualism, diversity in language education and critical pedagogy. 